\title{
Identificación microquímica de mármol blanco de Macael en varios monumentos españoles
}

\section{Microchemical identification of macael white marble in some spanish monuments}

\author{
M. A. BELLO, L. MARTIN y A. MARTIN \\ Departamento de Química Analítica \\ Facultad de Química \\ Universidad de Sevilla \\ c/ Prof. García González, s/n. 41012 Sevilla \\ ESPANNA
}

Fecha de recepción: 13-11-92

\section{RESUMEN}

Ha sido confirmado el empleo del mármol blanco procedente de las canteras de Macael (Almería) en varios monumentos del Sur de España; también se ha constatado el empleo de otros tipos de mármol blanco. La identificación del mármol de Macael mediante técnicas microquímicas ha sido realizada mediante un método gráfico propuesto por los autores (1). Han sido analizados catorce elementos traza en las muestras de cantera y de los edificios mediante espectrofotometría de absorción atómica y de emisión de llama, al objeto de construir los diagramas de enriquecimiento de elementos traza (EDTE). con fines de identificación.

\author{
$S \cup M M A R Y$
}

The white marble from Macael quarries (Almeria, Spain) has been identified in some monuments of the Southern of Spain; the use of other white marble types has also been confirmed. The microchemical identification has been carried out by means a previously described graphical method (Bello and Martin, 1991). Fourteen trace elements have been analyzed from both quarry and building material samples by using atomic absorption and flame emission spectrometry in order to apply the enrichment diagrams for trace elements (EDTE) for identification purposes

\section{INTRODUCCIÓN}

Uno de los principales problemas en arqueometría es la determinación de la procedencia de materiales y objetos. Cuando se habla de mármol blanco, uno de los materiales más comúnmente empleado en edificios y estatuas, el problema más frecuente a resolver es la determinación del origen del material empleado. Esta información es usada en arqueología, en estudios relacionados con la historia del arte y muy especialmente para propuestas de restauración.

\section{INTRODUCTION}

A major topic in archaeometry is the provenance determination of artifacts. When speaking about white marble, one of the mosi common building and sculpture stones, the problem to be solved mostly concerns the origin of the raw material. This information is used in archaeology to reveal trade patterns and economical organization, as well as in art historical studies and for restoration purposes. 
Para la identificación de mármoles han sido empleadas muchas técnicas simples o combinadas. En el siglo XIX, los geólogos confiaban en poder distinguir las diversas canteras de mármoles mediante métodos petrográficos; en 1890, Lepsius (2) identificó la procedencia de más de 400 estatuas clásicas pertenecientes a diversos museos europeos por estos métodos. En 1898, H. S. Washington (3) advirtió que asignar la procedencia y correcta asociación de fragmentos de objetos era de mucha mayor complejidad que la asumida por Lepsius. Washington sugirió que eran necesarios unos detallados estudios geológicos, petrográficos y químicos antes de poder asignar correctamente la procedencia de cualquier material.

Actualmente, para propuestas de identificación están siendo usadas diversas técnicas además de los métodos petrográficos; así, la determinación del contenido de diversos elementos en concentraciones traza y su posterior tratamiento estadístico y/o gráfico es muy empleada; para estas determinaciones se usan muy diversas técnicas: el análisis por activación neutrónica es muy empleado por su carácter multielemento y elevada sensibilidad (4-6); espectrofotometría de absorción atómica (1); fluorescencia de rayos $X$ (7-9); ... Otro método usado es la determinación de la relación entre determinados isótopos: ${ }^{13} \mathrm{C} /{ }^{12} \mathrm{C}$ y ${ }^{18} \mathrm{O} /{ }^{16} \mathrm{O}(10,11),{ }^{87} \mathrm{Sr} /{ }^{86} \mathrm{Sr}(12-14)$.

Las primeras referencias del uso de los mármoles de Macael son del período romano (siglos I-II), y se empleó para lápidas funerarias y columnas de algunos teatros. No obstante, la explotación a gran escala comienza durante el período árabe (siglos $\mathrm{X}$ al XV). La explotación de las canteras de Macael ha continuado hasta nuestros días y constituyen actualmente las más importantes canteras españolas de mármol.

De acuerdo con un artículo previo (1), ha sido determinado el contenido de varios elementos traza en muestras de las canteras de Macael y en muestras de diversos monumentos españoles, y los resultados han sido tratados gráficamente usando EDTE (representaciones gráficas de la composición microquímica donde los diferentes elementos y sus concentraciones en ppm (escala logarítmica) constituyen los ejes $x \in y$, respectivamente) con el propósito de verificar el uso de mármol blanco de Macael en los monumentos estudiados.
For the identification of marbles, many techniques or multi-method approach applying different techniques have been used. At the 19th-century, geologists attempted to distinguish marble quarries by petrographic methods; in 1890 Lepsius identified the sources of over 400 classical statues in European museums by these methods. In 1898, H. S. Washington warned that assigning the provenance and correctly associating fragments of artifacts were much more difficult endeavors than Lepsius assumed. Washington suggested that detailed geological, petrographical, and chemical studies of the individual quarries were needed before anyone could assign a provenance to any artifact.

Nowadays, diverse techniques are using for stone identification purposes moreover the petrographic methods; so, the contents of diverse trace elements and their latter statistical or graphical treatment have been used; diverse techniques have been employed for these determinations: neutron activation analysis is widely used because its multielement character and high sensitivity (i.e. Moens et al, 1988; Mello et al, 1988; ...); atomic absorption spectrometry (Bello and Martín, 1991); $X$-ray fluorescence spectrometry (Matsumoto and Fuwa, 1979; Yap, 1988; Willians-Thorpe, 1988). Other method used is the determination of some stable isotopes and their relationships: ${ }^{13} \mathrm{C} /{ }^{12} \mathrm{C}$ and ${ }^{18} \mathrm{O} /{ }^{16} \mathrm{O}$ (Herz, 1985 and 1988), ${ }^{87} \mathrm{Sr}{ }^{\beta 6} \mathrm{Sr}$ (Herz et al, 1982; Herz and Dean, 1986; Herz, 1987).

The first references of the use of the Macael marbles are of the roman age (1st-2nd centuries) for tomb-stones and for the columns of some theaters. However, their important exploitation start in the arabian age (10th to 15th centuries). The exploitation of the Macael quarries have been continued and nowadays they constitute the more important spanish quarries of marble.

According to a previous work (Bello and Martín, 1991), the contents of some trace elements in Macael quarry samples and those corresponding to some samples from diverse Spanish monuments have been determined and the results have been graphically treated by means of EDTE (graphical plots of the microchemical composition, where the different elements and their concentrations in ppm (log-scale) are related to $x$ and $y$ axis) with the aim to verify the use of Macael white marble in those monuments. 


\section{PARTE EXPERIMENTAL}

\subsection{Procedimiento}

Las muestras de mármol, profundas e inalteradas, son pulverizadas en mortero de ágata y secadas a $110^{\circ} \mathrm{C} ; 0,7 \mathrm{~g}$ de muestra se funden con $2 \mathrm{~g}$ de metaborato de litio a $950^{\circ} \mathrm{C}$ en un crisol de platino. El fundido, una vez frío, se extrae con solución de ácido nítrico al $5 \%(\mathrm{v} / \mathrm{v})$. El extracto se trasvasa a un matraz aforado de $100 \mathrm{ml}$ y se enrasa con solución de $\mathrm{HNO}_{3}$ al $5 \%(\mathrm{v} / \mathrm{v})$; la solución así obtenida es almacenada en frascos de polietileno. Los contenidos de Rb, Cs, Sr, Ti, $\mathrm{Cr}, \mathrm{Mo}, \mathrm{Mn}, \mathrm{Ni}, \mathrm{Cu}, \mathrm{Zn}, \mathrm{Cd}, \mathrm{Sn}, \mathrm{Pb}$ y Sb se determinan en esta solución. Todas las medidas fueron realizadas en un espectrofotómetro de absorción atómica Perkin-Elmer 2380. Rubidio y cesio fueron determinados por emisión de llama (FES) y los restantes por absorción atómica (AAS).

\subsection{Muestras de cantera y de monumentos}

La zona de Macael está situada en el sector oriental de la cordillera Bética (zona "NevadoFilábride"); las unidades en las que se encuentran las canteras de mármol son "Nevado-Lubrín" y "Bedar-Macael", de la era Triásica. El metamorfismo y posteriores deformaciones de estos materiales corresponden a la era Alpina. Las canteras incluyen mármoles blancos, grises y verdes, siendo los blancos los de mayor importancia, cuyas bancadas de 50-100 m de potencia permiten la obtención de grandes bloques. Presentan un color blanco uniforme y grano medio y muy puro; en algunos casos pueden observarse ligeros veteados de calcita asociada a láminas de moscovita.

La Figura 1 muestra, sobre un mapa de la zona de Macael, la localización de las muestras tomadas para este estudio. La denominación que recibe cada zona de las canteras en las que han sido tomadas las muestras puede observarse en la Tabla 1.

Para la identificación de mármol blanco de Macael en monumentos, fueron tomadas muestras de columnas y figuras escultóricas de la Alhambra de Granada (ALH), de la solería de la Catedral de Almería (AL), de columnas de la Catedral de Cádiz (CA), de la fachada principal del Palacio de San Telmo en Sevilla (ST) y de restos de columnas del Teatro Romano de Itálica en Santiponce (Sevilla) (ITA).

\section{EXPERIMENTAL}

\subsection{Procedure}

Deep and unaltered samples of the marble samples were powdered in an agate mortar and then, dried at $110^{\circ} \mathrm{C} .0,7 \mathrm{~g}$ of this sample was fused with $2 \mathrm{~g}$ of lithium metaborate at $950^{\circ} \mathrm{C}$ in a platinum crucible. The flux was extracted with a $5 \%(\mathrm{~V} / \mathrm{v}) \mathrm{HNO}_{3}$ solution. The extract was transferred into a $100 \mathrm{ml}$-calibrated flask and then diluted to the gauge-mark with $5 \%(\mathrm{v} / \mathrm{V}) \mathrm{HNO}_{3}$ solution. The solution obtained was stored in polyethylene flasks. The contents of $\mathrm{Rb}, \mathrm{Cs}, \mathrm{Sr}$, $\mathrm{Ti}, \mathrm{Cr}, \mathrm{Mo}, \mathrm{Mn}, \mathrm{Ni}, \mathrm{Cu}, \mathrm{Zn}, \mathrm{Cd}, \mathrm{Sn}, \mathrm{Pb}$ and $\mathrm{Sb}$ were determined in this solution. All measurements were carried out in a Perkin-Elmer 2380 Atomic Absorption Spectrometer. Rubidium and cesium were determined by FES and the other elements by AAS.

\subsection{Quarry and monument samples}

The region of Macael is located in the eastern sector of the Betic chain ("Nevado-Filábride" zone); the units which include the marble quarries are the "Nevado-Lubrín" and the "Bedar-Macael", of Triassic era. Their metamorphism and the latter deformations of these materials are of Alpine age. The quarries include white, grey and green marbles; the more important are the white ones, whose benches of 50-100 m of power permit the obtention of big marble blocks. Show an uniform white color with medium and very pure grain; in some cases, a light veined of calcite associated to the moscovite sheets can be observed.

Figure 1 shows, on a map of the Macael zone, the location of the samples taken for this study. The denomination of each quarry zone corresponding to the samples collected can be observed in table 1.

For the identification of Macael white marble, some samples of diverse spanish monuments have been collected: Alhambra of Granada (ALH), corresponding to columns and ornamental figures of the monument; Cathedral of Almería ( $A L)$, from the cathedral pavement; Cathedral of Cádiz (CA) from the columns; San Telmo Palace of Seville (ST), from the main facade of the building; and Roman Theater of Itálica, Seville (ITA), which correspond to remain of the columns. 
Fig. 1.-Localización de las muestras tomadas en las canteras de Macael.

Fig. 1. Location of the quarry samples from Macael.

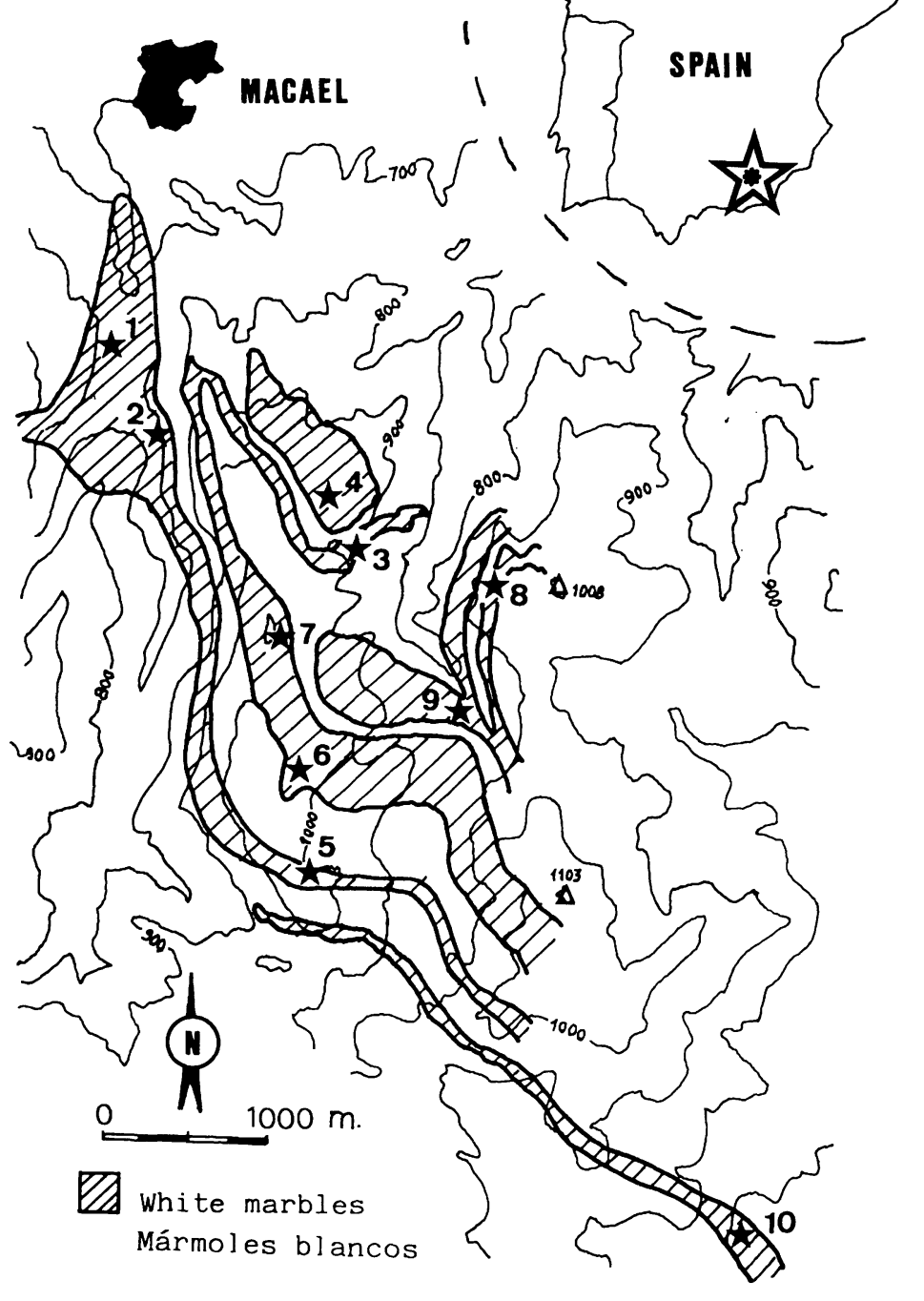

TABLA 1 TABLE 1

Procedencia de las muestras de las canteras de Macael Provenance of the quarry samples from Macael

\begin{tabular}{|l|l|}
\hline Muestra & \multicolumn{1}{|c|}{ Procedencia } \\
Sample & Source \\
\hline MACAEL 1 & Stratum "Rio" \\
MACAEL 2 & Stratum "Rio" \\
MACAEL 3 & Stratum "Los Hoyos", lower leve1: "E1 Paso" \\
MACAEL 4 & Stratum "Los Hoyos", upper leve1 \\
MACAEL 5 & Stratum "Austra1ia" \\
MACAEL 6 & Stratum "Cañai11a: Los Azules" \\
MACAEL 7 & Stratum "Cañai11a" \\
MACAEL 8 & Stratum "Cerro Pelao", upper 1eve1 \\
MACAEL 9 & Stratum "Barranco Arispe", upper leve1 \\
MACAEL 10 & Stratum "Chercos \\
\hline
\end{tabular}


TABLA 2 TABLE 2

Rangos de concentración (ppm) y valores medios para las canteras de Macael (10 muestras) [Concentration ranges (ppm) and average values for the Macael quarries (10 samples)]

\begin{tabular}{|c|c|c|c|c|c|}
\hline & $\begin{array}{l}\text { RANGO } \\
\text { RANGE }\end{array}$ & $\begin{array}{l}\text { MEDIA } \\
\text { AVERAGE }\end{array}$ & & $\begin{array}{l}\text { RANGO } \\
\text { RANGE }\end{array}$ & $\begin{array}{l}\text { MEDIA } \\
\text { AVERAGE }\end{array}$ \\
\hline $\begin{array}{l}\mathrm{Rb} \\
\mathrm{Cs} \\
\mathrm{Sr} \\
\mathrm{Ti} \\
\mathrm{Cr} \\
\mathrm{Mo} \\
\mathrm{Mn}\end{array}$ & 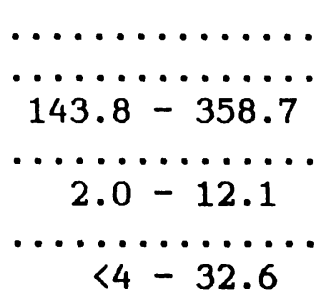 & $\begin{array}{c}<2 \\
<2 \\
229.6 \\
<120 \\
7.8 \\
<35 \\
16.3 \text { (非) }\end{array}$ & $\begin{array}{l}\mathrm{Ni} \\
\mathrm{Cu} \\
\mathrm{Zn} \\
\mathrm{Cd} \\
\mathrm{Sn} \\
\mathrm{Pb} \\
\mathrm{Sb}\end{array}$ & 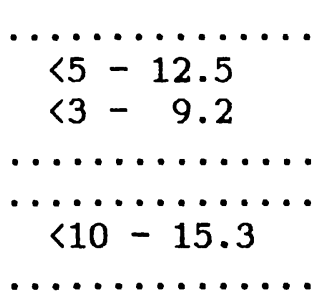 & $\begin{array}{c}<2 \\
6.6 \text { (非) } \\
4.0 \text { (非) } \\
<1 \\
<230 \\
11.2 \text { (非) } \\
<2\end{array}$ \\
\hline
\end{tabular}

(\#) Considerando el límite inferior como el valor correspondiente.

(\#) Considering the lower range as the corresponding value.

TABLA 3 TABLE 3

Valores de concentración (ppm) para las muestras de los diversos monumentos estudiados [Concentration values (ppm) for the samples from the diverse monuments studied]

\begin{tabular}{|c|c|c|c|c|c|c|c|c|c|c|c|c|c|c|}
\hline $\begin{array}{l}\text { Sample } \\
\text { Huestra }\end{array}$ & $\mathbf{R b}$ & Cs & Sr & $T \mathbf{i}$ & Cr & ио & Kn & Ni & $\mathrm{Cu}$ & $\mathbf{Z n}$ & Cd & Sn & $\mathbf{P b}$ & Sb \\
\hline$A L H-1$ & $<2$ & $<2$ & 200.1 & $<120$ & 11.0 & $<35$ & 13.0 & $<2$ & $<5$ & 3.3 & $<1$ & $<230$ & $<10$ & $<2$ \\
\hline ALH -2 & $<2$ & $<2$ & 192.6 & $<120$ & 9.8 & $<35$ & 23.1 & $<2$ & $<5$ & $<3$ & $<1$ & $<230$ & $<10$ & $<2$ \\
\hline ALH -3 & $<2$ & $<2$ & 177.9 & $<120$ & 7.3 & $<35$ & 9.7 & $<2$ & $<5$ & $<3$ & $<1$ & $<230$ & $<10$ & $<2$ \\
\hline ALH-4 & $<2$ & $<2$ & 249.4 & $<120$ & 10.4 & $<35$ & 28.5 & $<2$ & $<5$ & 4.6 & $<1$ & $<230$ & 12.5 & $<2$ \\
\hline ALH-5 & $<2$ & $<2$ & 178.1 & $<120$ & 10.8 & $<35$ & 8.6 & $<2$ & $<5$ & $<3$ & $<1$ & $<230$ & 13.8 & $<2$ \\
\hline$A L-335$ & $<2$ & $<2$ & 193.1 & $<120$ & 3.5 & $<35$ & 30.5 & $<2$ & 11.2 & 4.2 & $<1$ & $<230$ & 14.0 & $<2$ \\
\hline$A L-342$ & $<2$ & $<2$ & 156.1 & $<120$ & 5.2 & $<35$ & 9.7 & $<2$ & $<5$ & 8.3 & $<1$ & $<230$ & 13.9 & $<2$ \\
\hline$S T-1$ & $<2$ & 32.7 & 177.5 & $<120$ & 10.6 & $<35$ & 35.5 & 4.3 & 32.7 & 8.5 & $<1$ & $<230$ & 14.2 & $<2$ \\
\hline$S T-2$ & $<2$ & 111.9 & 70.4 & $<120$ & 12.3 & $<35$ & 38.0 & 4.2 & $<5$ & 21.1 & $<1$ & $<230$ & 30.1 & $<2$ \\
\hline $\mathrm{ST}-3$ & $<2$ & 41.2 & 106.8 & $<120$ & 3.6 & $<35$ & 17.1 & $<2$ & $<5$ & $<3$ & $<1$ & $<230$ & $<10$ & $<2$ \\
\hline$C A-2$ & $<2$ & $<2$ & 103.9 & $<120$ & 10.4 & $<35$ & 46.2 & 5.0 & $<5$ & 8.3 & $<1$ & $<230$ & 13.9 & $<2$ \\
\hline$C A-38$ & $<2$ & 6.0 & 65.8 & $<120$ & 3.0 & $<35$ & 73.1 & 6.3 & 20.0 & 5.1 & $<1$ & $<230$ & 32.3 & $<2$ \\
\hline ITA-1 & $<2$ & $<2$ & 177.8 & $<120$ & 7.1 & $<35$ & $<4$ & $<2$ & $<5$ & $<3$ & $<1$ & $<230$ & $<10$ & $<2$ \\
\hline ITA-2 & $<2$ & $<2$ & 174.2 & $<120$ & 7.0 & $<35$ & 9.8 & $<2$ & $<5$ & 7.0 & $<1$ & $<230$ & $<10$ & $<2$ \\
\hline ITA-3 & $<2$ & $<2$ & 206.4 & $<120$ & 5.2 & $<35$ & 136.2 & $<2$ & $<5$ & $<3$ & $<1$ & $<230$ & $<10$ & $<2$ \\
\hline ITA-4 & $<2$ & $<2$ & 224.0 & $<120$ & 6.9 & $<35$ & 24.8 & $<2$ & $<5$ & 4.1 & $<1$ & $<230$ & 13.8 & $<2$ \\
\hline ITA-5 & $<2$ & $<2$ & 232.3 & $<120$ & 5.4 & $<35$ & 8.6 & $<2$ & $<5$ & $<3$ & $<1$ & $<230$ & 14.3 & $<2$ \\
\hline ITA-6 & $<2$ & $<2$ & 195.2 & $<120$ & 7.1 & $<35$ & 149.1 & $<2$ & $<5$ & $<3$ & $<1$ & $<230$ & 14.2 & $<2$ \\
\hline ITA-7 & $<2$ & $<2$ & 177.3 & $<120$ & 8.9 & $<35$ & 12.8 & $<2$ & $<5$ & 14.3 & $<1$ & $<230$ & $<10$ & $<2$ \\
\hline
\end{tabular}




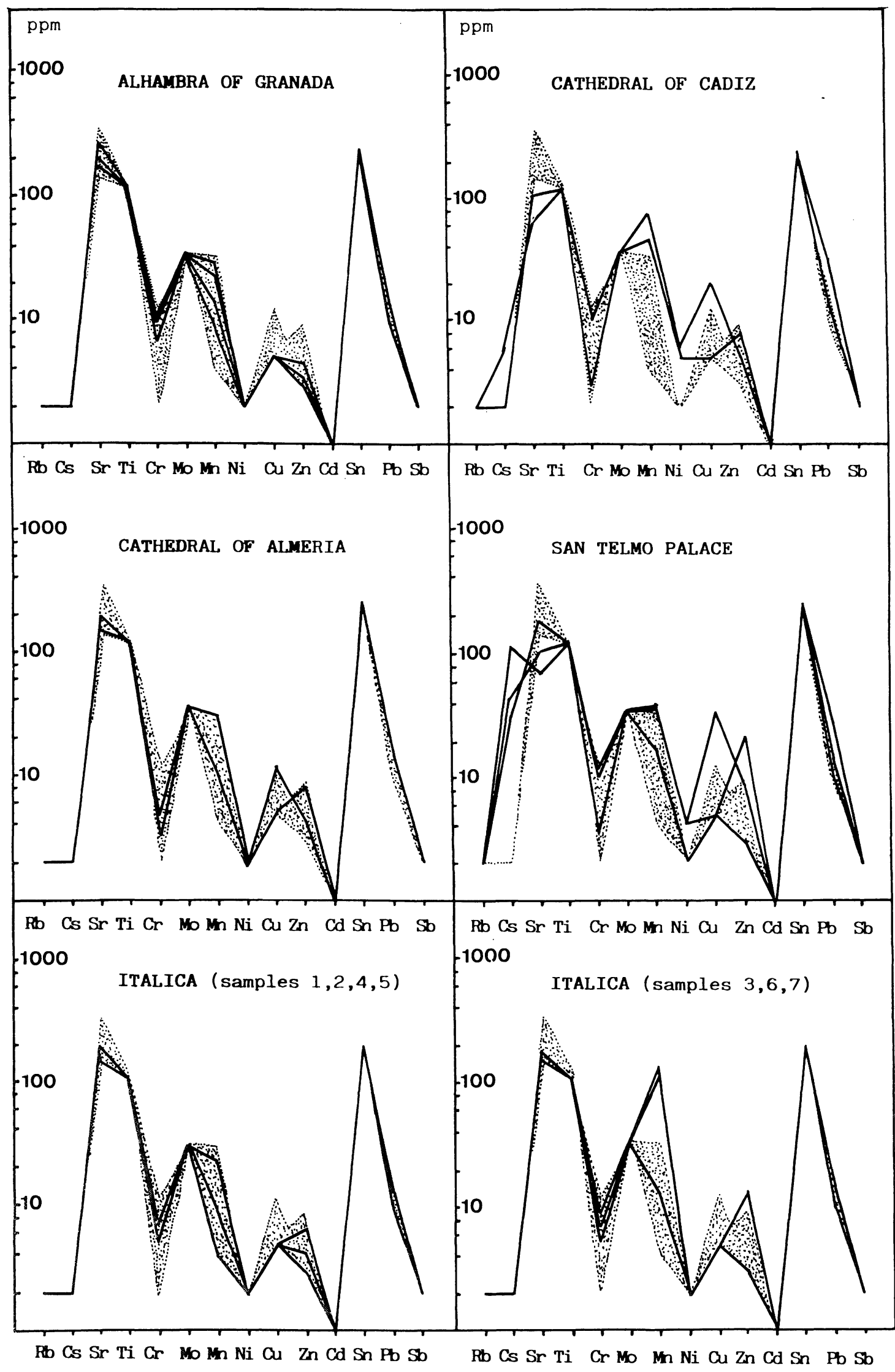

Fig. 2.-Diagramas de enriquecimiento de elementos traza (EDTE) correspondientes a las muestras de monumento estudiadas comparadas con los límites establecidos (punteado) para las canteras de mármol blanco de Macael.

Fig. 2. - Comparison of the enrichment diagrams for trace elements (EDTE) corresponding to the monument samples studied with the EDTE limits (dotted) for the Macael white marble quearries.

28

MATERIALES DE CONSTRUCCION, Vol. 42, n. ${ }^{\circ} 225$, enero/febrero/marzo 1992

(C) Consejo Superior de Investigaciones Científicas

http://materconstrucc.revistas.csic.es

Licencia Creative Commons 3.0 España (by-nc) 


\section{RESULTADOS Y DISCUSIÓN}

En primer lugar, fueron analizadas las muestras de mármol blanco correspondientes a las diversas zonas de las canteras de Macael; en la Tabla 2 aparecen los rangos de concentración y la media para cada elemento analizado. Todas las muestras de cantera analizadas definen los límites de EDTE característicos para el mármol blanco de Macael, que aparecen punteados en la Figura 2 con los correspondientes EDTE de las diversas muestras de monumentos; los valores de concentración para estas muestras aparecen en la Tabla 3.

Como se puede observar en la Figura 2, los EDTE de las muestras correspondientes a la Alhambra de Granada, Catedral de Almería y las muestras 1, 2, 4 y 5 del Teatro de Itálica, quedan dentro de los límites definidos para las canteras de Macael, lo que indica que proceden de dichas canteras.

Para las muestras de la Catedral de Cádiz, Palacio de San Telmo y muestras 3,6 y 7 del Teatro de Itálica, los correspondientes EDTE no quedan dentro de los límites definidos por las canteras de Macael, y es posible concluir, por tanto, que corresponden a mármoles blancos de otra $u$ otras procedencias.

Los resultados obtenidos confirman antiguas referencias sobre el uso de mármol blanco de Macael en algunos de los monumentos estudiados. Así, existen referencias acerca del uso de este material en la Alhambra de Granada, Catedral de Almería y en el Teatro Romano de Itálica; para este último monumento existen, asimismo, referencias sobre el uso de otros mármoles blancos. Para el Palacio de San Telmo y la Catedral de Cádiz, no existe ninguna documentación acerca del uso de mármol de Macael; los resultados obtenidos indican que, efectivamente, han sido empleados mármoles de otras procedencias.

\section{CONCLUSIONES}

Los EDTE han sido usados con anterioridad para la identificación de diversas calizas sedimentarias (1); en este artículo, queda demostrada la utilidad de este procedimiento para la identificación de otros materiales pétreos como son los mármoles blancos; el método ha sido aplicado con éxito a la identificación del más importante mármol blanco de España en algunos monumentos, y podría ser empleado para su identificación en otros monumentos donde existiesen dudas; el método podría ser usado, asimismo, para el estudio de otras canteras.

\section{RESULTS AND DISCUSSION}

In first place, the samples of white marble corresponding to the diverse quarry zones were analyzed; table 2 shows the concentration range and the average for each element. All the quarry samples analyzed define the graphical limits of the EDTE plots for the Macael white marble, which appear dotted in figure 2 with the corresponding EDTE of the diverse monument samples analyzed. Table 3 shows the concentration values of the monument samples.

As can to be observed in figure 2, the EDTE of the samples corresponding to Alhambra of Granada, Almeria Cathedral and the samples 1, 2, 4 and 5 of the Roman Theater of Itálica, are between the EDTE limits defined for the Macael quarries, which indicate those samples are from Macael.

For the Cádiz Cathedral, San Telmo Palace and the samples 3, 6 and 7 of the Roman Theater of Itálica, the corresponding EDTE are not between the Macael EDTE limits, and it is possible to conclude that other white marbles have been used.

The results obtained confirm some ancient references about the use of the Macael white marble in some of the monuments. So, some references of its use exist for the Alhambra of Granada, Cathedral of Almeria and Roman Theater of Itálica, for this last monument, some references about the use of other white marbles also exist. For the San Telmo Palace and the Cathedral of Cádiz, do not exists any documentation of the use of the Macael marble; the results confirm that those used white marbles are from other different quarries.

\section{CONCLUSIONS}

The EDTE have been previously used for the identification of diverse sedimentary limestones (Bello and Martin, 1991); in this work, the validity of this procedure for the identification of other stony materials, like white marbles, has been demonstrated and applied to the identification of the more important Spanish white marble. This method can be used for the identification of this marble in other monuments, and it should can be used for other quarries studies. 


\section{AGRADECIMIENTO}

Los autores desean expresar su agradecimiento al Dr. Eduardo Mayoral del Departamento de Geología y Minería de la Universidad de Sevilla por el muestreo de las canteras y los estudios geológicos.

\section{ACKNOWLEDGEMENTS}

We greatly appreciate the collaboration of Dr. Eduardo Mayoral (Department of Geology and Mining of the Seville University) for the obtention of the quarry samples and the geological studies.

\section{REFERENCIAS (REFERENCES)}

(1) BELLO, M. A.; MARTIN, A.: "Microchemical characterization of building stones from The Cathedral of Seville (Spain)". Archaeometry, in press.

(2) LEPSIUS, G. R.: "Griechische Marmorstudien", Ed. Königliche Akademie der Wissenschaften, Berlin, 1890.

(3) WASHINGTON, H. S.: "The identification of the marbles used in Greek sculpture", American Journal of Archaelogy, Vol. 2, $1898,1-18$.

(4) MOENS, L.; ROOS, P.; DE RUDDER, J.; HOSTE, J.; DE PAEPE, P.; VAN HENDE, J.; MARECHAL, R.; WAELKENS, M.: "White marble from Italy and Turkey: an archaeometric study based on minor and trace-element analysis and petrography", Journal of Radioanalytical and Nuclear Chemistry, Articles, Vol 123, No 1, 1988, 333-348.

(5) MELLO, E.; GALANTE, F.; MELONI, S.; ODDONE, M.; PONTICELLI, S.: "Etudes sur la provenance du marbre blanc du Dôme de Côme au moyen de l'activation neutronique et de l'elaboration statistique des données obtenues", Proc. 4 th Intern. Cong. on the Deterioration and Preservation of Stone Objects, Louisville (Kentucky), Ed. K. L. Gauri and J. A. Gwinn, $1982,251-259$.

(6) MELLO, E.; MONNA, D.; ODDONE, M.: "Discriminating sources of Mediterranean marbles. A pattern recognition approach", Archaeometry, 30, 1, 1988, 102-108.

(7) MATSUMOTO, K.; FUWA, K.: "Major and trace elements determination in geological and biological samples by energydispersive X-ray fluorescence spectrometry", Analytical Chemistry, 51, 1979, 2355-2358.

(8) YAP, C. T.: "A quantitative spectrometric analysis of trace concentrations of manganese and cobalt in ceramics and the significance of As/Co and Mn/Co ratios", Journal of Archaeological Science, 15, 1988, 173-177.

(9) WILLIANS-THORPE, O.: "Provenancing and archaeology of Roman millstones from Mediterranean area", Journal of Archaeological Science, 15, 1988, 253-305.

(10) HERZ, N.: "Stable isotopic signatures applied to problems of classical greek marble", National Geographic Society, Research Reports, Vol. 20, 1985, 353-363.

(11) HERZ, N.: "Classical marble quarries of thasos", in Antike Edel-und Bunt-metallgewinnung auf Thasos, Ed. G. A. Wagner \& G. Weisgerber editors, Bochum, 1988.

(12) HERZ, N.; MOSE, D. G.; WENNER, D. B.: "87 Sr $/{ }^{86}$ Sr ratios: a possible discriminant for classical marble provenance", Geological American Society, Abs. Prog., 14, 1982, 514

(13) HERZ, N.; DEAN, N.: "Stable isotopes and archaeological geology: the Carrara marble, northern Italy", Applied Geochemistry, Vol 1, 1986, 139-151.

(14) HERZ, N.: "Carbon and oxygen isotopic ratios: a data base for classical greek and roman marbles", Archaeometry, 29, 1, 1987, 35-43. 